\title{
NEWS ITEMS
}

\section{The Donald Winnicott Centre}

For reasons which remain obscure, our main medical journals overlooked the opening of the Donald Winnicott Centre by the Minister for the Disabled, Mr Alfred Morris, M.P., on 26 October 1978.

Some half a million pounds, mainly donated by the Hayward Foundation, has produced a handsome building at the Queen Elizabeth Hospital for Children, Hackney Road, London, where Dr Winnicott was a paediatrician for twelve years. The centre is designed to provide a combined psychiatric and paediatric assessment facility, with, in addition, one of the most sophisticated audiological units for children yet designed in the United Kingdom. The Warnock Report places the under-fives as first priority.

From concept to completion has taken about ten years, and it is gratifying that one of the most distinguished child psychiatrists in the world has been commemorated, and his journey from paediatrics to psychiatry both embodied in stone and blessed.

ANDREW Crow Croft

Working Party on Observation and Assessment

The Department of Health and Social Security has set up a working party to look into present practices in the observation and assessment of children and young persons referred to local authority social services departments, and to explore the possibilities of developing such observation and assessment other than in residential community homes.

It is hoped that publicity will stimulate interest and will assist the work of the Committee by bringing in ideas. Indeed, any relevant information, advice or ideas from interested individuals, authorities, or organisations would be welcomed.

Excerpta Medica Travel Award, 1979

Applications are invited for the Excerpta Medica Travel Award for 1979. The Award, which lasts for three months and covers travel and hotel costs, is open to medical specialsts born during or after 1943. A married recipient may be accompanied by husband or wife. Applications, enclosing: Curriculum vitae (and a recent photograph); list of publications, plus reprints; two letters of recommendation; and a statement of approximately 250 words indicating how the Award would be used, should be sent to: Mr Kenneth Ellison Davis, Travel Award Office, Excerpta Medica Foundation, P.O. Box 1126, 1000 BC Amsterdam, The Netherlands, by 1 March.

\section{Research Programme on Social Skills Behavioural} Psychotherapy

A research programme is in progress at the Institute of Psychiatry for investigating the treatment of patients who have social skills problems without schizophrenia or severe depression. Treatment involves 14 sessions of group social skills training with or without additional training in cognitive coping mechanisms. Patients who are referred with such problems can be offered a rapid appointment for assessment for possible treatment. Referrals should be directed to Professor Isaac Marks, Institute of Psychiatry, De Crespigny Park, Denmark Hill, London SE5 8AF.

\section{FORTHCOMING EVENTS}

\begin{abstract}
Association of Psychiatrists in Training
An Open Forum on 'Who puts medical students off psychiatry?' will be held on Tuesday, 6 February, at the London Hospital, Whitechapel, E1. The speakers will include Professor Gerald Russell, Professor Henry Walton, a non-psychiatrist, and medical students. All are welcome. Further details from $\mathrm{Dr}$ F. Creed, Department of Psychiatry, The London Hospital.
\end{abstract}

\section{Winnicott Fund}

The fourth Winnicott Conference will be held at Bedford College, Regent's Park, London, on Friday, 23 March. The theme is 'Containing Stress in Profes- sional Work'. Application forms from Mrs J. Coles, 1 Anne Mount, 44 Madeley Road, London, W5 2LU.

\section{Association of Therapeutic Communities}

The Annual General Meeting and a day conference with the theme, 'Love, Hate and Analysis in Therapeutic Communities' will be held at St Bernard's Hospital, Southall, on Saturday, 24 February. Details and application form from $\mathrm{Dr} \mathrm{H}$. Bourne, Connolly Unit, St Bernard's Hospital, Southall, Middlesex.

The second residential training weekend, 'Learning from Experience in Therapeutic Community Living', will be held from 23-25 March. Further details and application forms from Dr Jeff Roberts, Ingrebourne Centre, St. George's Hospital, Hornchurch, Essex. 
British Psycho-Analytical Society

There will be a day of talks and discussion on 'The Everyday Life of the Family: a Psycho-Dynamic View' on 17 February, and a one-day course on 'Basic Psycho-Analytical Concepts' on 24 March. Details are obtainable from the Hon. Organizing Secretary, Public Lectures Committee, The British PsychoAnalytical Society, $63 \mathrm{New}$ Cavendish Street, London, WIM 7RD.

\section{Introduction to Neuropsychology}

This two-day conference, presented by the Yorkshire Regional Branch of the Division of Clinical Psychology, St James's University Hospital, Leeds, will be held in Harrogate on 10 and 11 May. The registration fee is $£ 20$ and applications must be returned before 14 February. Further information from Mrs Una P. Holden, Chairman YRBDCP, North Side, St James's Hospital, Leeds, LS9 7TF.

\section{Association of Reporters to Children's Panels}

The Annual Conference is to be held at the Atholl Palace Hotel, Pitlochry, on 30 March-1 April, and non-members of the Association are invited. The theme is 'Discretion as exercised within the Children's Hearings System is guided by the principle-the best interest of the child. (Section 43(1), Social Work (Scotland) Act 1968): What is the best interest of the child?' Details from Mr J. Hutcheson, Depute Reporter to the Children's Panel (Perth Division), Tayside Regional Council, York Place, Perth, Scotland.
British Association for Behavioural Psychotherapy

The Annual Workshops for 1979 will be held at the University of Reading from 31 March-1 April. Further details and application forms from Rod Holland, Senior Clinical Psychologist, Alton Health Centre, Anstey Road, Alton, Hampshire.

\section{Alcoholism Treatment: Finding New Directions}

This major international conference, sponsored by the Addiction/Dependence Group of the Royal College of Psychiatrists, the Alcohol Education Centre, the ARF (Toronto) and the NIAA (Washington), will be held at the Institute of Psychiatry, London, from 23-30 April. Further information from the Alcohol Education Centre, 99 Denmark Hill, London, SE5 8AF.

\section{Postgraduate Course on Behavioural Psychotherapy}

This non-residential 3-day course for professionals with at least 2 years' clinical experience in psychiatric settings will be held at the Institute of Psychiatry, 1113 June. The fee is $£ 49$ and numbers will be limited. Applications, together with curriculum vitae stating degrees and experience, to Professor I. M. Marks, Institute of Psychiatry, De Crespigny Park, Denmark Hill, London SE5 8AF. 